\title{
Penentuan Kebutuhan Tenaga di RS HVA Toeloengredjo dengan Metode Workload Indicators of Staffing Need (WISN) untuk Efisiensi Sumber Daya Manusia
}

\section{Determining Employee Needs in HVA Toeloengredjo Hospital based on Workload Indicators of Staffing Need (WISN) Method for Human Resource Efficiency}

\author{
Wahjoe Harijanto ${ }^{1}$, FX Retriatmadja Moestopo ${ }^{2}$, Yetty Nusaria $\mathrm{Nl}^{3}$ \\ ${ }^{1}$ Rumah Sakit Gatoel Mojokerto \\ ${ }^{2}$ Program Studi Magister Manajemen Rumah Sakit Fakultas Kedokteran Universitas Brawijaya Malang \\ ${ }^{2}$ Rumah Sakit HVA Toeloengredjo Pare Kediri
}

\begin{abstract}
ABSTRAK
Rumah sakit harus mampu memenuhi kebutuhan tenaga kerja secara efisien tanpa mengorbankan kualitas pelayanan, guna meningkatkan daya saingnya. Workload Indicators of Staffing Need (WISN) adalah suatu metode untuk menghitung kebutuhan tenaga kerja berdasarkan beban kerja. Metode yang digunakan adalah Workload Indicators of Staffing Need (WISN). Metode ini membandingkan kondisi ketenagaan riil dengan hasil penghitungan WISN. Dari rasio WISN bisa diketahui kelebihan atau kekurangan tenaga kerja yang ada. Unit yang diteliti ada 19 sub-divisi dari Divisi Pelayanan medis, Divisi Penunjang Medis dan Divisi Keperawatan. Dari penghitungan WISN terhadap 19 sub-divisi dihasilkan kebutuhan tenaga berdasarkan beban kerja tahun 2012 sebesar 158 orang dan saat ini terdapat 199 orang, sehingga terdapat kelebihan 41 orang. Rasio WISN yang dihasilkan sebesar 1,26 menunjukkan terjadi kelebihan tenaga lebih dari $25 \%$ dari kebutuhan yang ada. Kelebihan tenaga kerja dari penghitungan WISN dikarenakan rendahnya kegiatan di beberapa unit pelayanan. Penyebab yang lain karena ada unit pelayanan dan unit penunjang yang dibuka 24 jam tujuh hari per mingguuntuk memberikan keunggulan pelayanan kepada pasien. Untuk memenangkan persaingan antar rumah sakit dengan menonjolkan pelayanan yang cepat dan berkualitas, pihak manajemen rumah sakit harus memenuhi kebutuhan tenaga kerja di unit pelayanan dengan melebihi dari kebutuhan beban kerja yang ada. Pelayanan yang cepat, tepat waktu, jam pelayanan, dan luas area rumah sakit memberikan pengaruh dalam pemenuhan kebutuhan tenaga kerja.
\end{abstract}

Kata Kunci: Beban kerja, efisiensi, sumber daya manusia, WISN

\begin{abstract}
Hospital must be able to meet the manpower requirements efficiently without sacrificing quality of service, in order to increase its' competitiveness. Workload Indicators of Staffing Need (WISN) is a method for calculating labor requirements based on workload. The method used is Workload Indicators of Staffing Need (WISN). The method compares the real condition workforce with the calculation results by WISN. The excess or deficiency of the existing workforce can be known from the WISN ratio. There are 19 sub-divisions of the Division of Medical Services, Medical Support Division and the Division of Nursing which were studied. According to WISN calculation on 19 sub-divisions, manpower needed based on workload in 2012 amounted to 158 people and there are currently 199 people, so there was an excess of 41 people. The excess of labor resulted from WISN ratio which is 1.26 indicates there is more than $25 \%$ of the existing needs. The excess of labor calculated is due to low activity in several service units. The other cause is the availability of services and support units 24 hours every day throughout the week to provide service excellence to patients. To win the competition among hospitals by offering fast and quality of services, the hospital management must meet the needs of workers in service unit by excessively fulfill the requirements according to the existing workload. Quick response, punctuality, opening hours and the area of hospital affect the fulfillment of labor needs.
\end{abstract}

Keywords: Efficiency, human resources, WISN, workload

Jurnal Kedokteran Brawijaya, Vol. 28, Suplemen No. 1, 2014: Wahjoe Harijanto. Rumah Sakit Gatoel Mojokerto, JI. Raden Wijaya Mojokerto 61321 Tel. (021) 52997777 Email: harijantowahjoe@gmail.com 


\section{PENDAHULUAN}

Pengembangan sumber daya manusia (SDM) membutuhkan biaya investasi dan merupakan aset perusahaan, karena SDM merupakan penghasil pendapatan rumah sakit. Pemenuhan kebutuhan SDM merupakan hal yang krusial bagi pengelola SDM perusahaan. Pengelola SDM harus mampu menghitung kebutuhan SDM secara tepat berdasarkan kebutuhan unit pelayanan. Kelebihan pemenuhan kebutuhan SDM memberikan konsekuensi biaya tenaga kerja yang tinggi dan menimbulkan ketidakefisienan dalam pengelolaan keuangan. Sebaliknya kekurangan pemenuhan kebutuhan SDM memberikan efek beban kerja yang tinggi kepada tenaga kerja dan berakibat bisa menurunkan kepuasan dalam bekerja, meningkatkan kejadian burnout, meningkatkan keinginan pindah kerja, menurunkan kualitas keselamatan pasien dan akhirnya akan menurunkan kualitas pelayanan kepada pasien $(1,2)$.

Perkembangan pelayanan Rumah Sakit HVA Toeloengredjo juga memerlukan pengembangan tenaga kerja setiap tahun agar terjadi keselarasan antara kegiatan dan kebutuhan sumber daya manusia. Setiap tahun di RS HVA Toeloengredjo terjadi penambahan tenaga kerja dari bermacam profesi. Penambahan tenaga kerja akan berimplikasi kepada peningkatan biaya SDM tetapi dilain pihak peningkatan aktivitas dan pelayanan rumah sakit berakibat meningkatkan biaya pengeluaran rumah sakit. Rasio biaya SDM terhadap biaya pengeluaran rumah sakit seharusnya selalu tetap tiap tahun atau tidak berfluktuasi terlalu tinggi. Rasio tersebut sebaiknya tidak melampaui $40 \%$ karena bila angka tersebut terlampaui akan menimbulkan ketidakefisienan di rumah sakit. Rasio biaya SDM dan biaya pengeluaran rumah sakit akan tercermin kepada unit cost tarif rumah sakit. Tingginya rasio tersebut mengakibatkan tarif rumah sakit menjadi mahal dan rumah sakit menjadi kurang kompetitif dalam persaingan.

Ketika rumah sakit bergabung menjadi provider Badan Penyelenggara Jaminan Sosial (BPSS) dalam Sistem Jaminan Sosial Nasional yang mulai berlaku pada tanggal 1 Januari 2014 perlu dikaji apakah unit cost rumah sakit untuk suatu pelayanan penyakit bisa lebih rendah dari tarif INA CBGs (Indonesian Case Based Groups). Bila unit cost lebih tinggi dari tarif INA CBGs maka bisa dipastikan rumah sakit tersebut akan merugi ketika menjadi provider BPJS. Rumah sakit yang mempunyai tenaga kerja berlebihan akan mempunyai pelayanan yang buruk. Ketika rumah sakit dibayar secara paket pelayanan seperti INA CBGs tentu akan mengimbangi pengeluaran biaya SDM dengan mengurangi biaya di pos lain, seperti biaya pelatihan, biaya adopsi teknologi baru danmengurangi pemeriksaan penunjang untuk pasien (3).

Data laporan keuangan RS HVA Toeloengredjo dari tahun 2008 hingga 2012 menunjukkan rasio antara biaya SDM terhadap biaya pengeluaran rumah sakit semakin meningkat dari 26,30\% di tahun 2008 meningkat hingga $31,75 \%$ di tahun 2012. Peningkatan ini mencapai 20\% lebih yang berarti meningkat rata-rata $5 \%$ pertahun. Apabila hal ini terjadi terus diprediksikan pada tahun 2018, rasio biaya SDM terhadap pengeluaran RS akan mencapai diatas $40 \%$. Kondisi tersebut akan menempatkan pihak manajemen pada posisi yang sulit karena rumah sakit berada pada posisi tidak efisien. Ketika itu terjadi manajemen rumah sakit akan sulit menurunkannya kembali karena biaya SDM telah menjadi pengeluaran rutin rumah sakit. Biaya SDM ini meliputi biaya gaji, lembur dan insentif untuk karyawan dan belum termasuk biaya perawatan kesehatan karyawan dan keluarganya serta tidak termasuk biaya pelatihan dan pendidikan. Penelitian ini akan menjawab apakah peningkatan rasio biaya SDM terhadap pengeluaran ini akibat pemenuhan kebutuhan tenaga kerja di unit- unit rumah sakit yang melebihi kebutuhan beban kerja.

Biaya operasional jasa dibentuk dari biaya bahan baku dan biaya tenaga kerja langsung yang keduanya merupakan biaya pokok dan ditambah biaya overhead operasional. Biaya tenaga kerja langsung dan biaya overhead operasional juga merupakan biaya konversi. Biaya tenaga kerja langsung merupakan biaya upah untuk membayar tenaga kerja langsung yang merupakan karyawan yang secara langsung ikut serta menghasilkan produk ataujasa seperti dokter dan perawat di Instalasi Gawat Darurat. Tenaga kerja tak langsung merupakan tenaga kerja yang aktivitasnya tidak secara langsung berhubungan dengan produk atau jasa tersebut dan upah yang diberikan merupakan biaya tenaga kerja tak langsung dan masuk dalam biaya overhead perusahaan. Ketiga biaya tersebut merupakan komponen utama dalam unit cost tarif rumah sakit $(4,5)$.

Penelitian ini dilakukan untuk menghitung kebutuhan riil tenaga kerja berdasarkan beban kerja yang ada sehingga dicapai keseimbangan antara tenaga kerja tersedia dengan beban kerja yang dihadapi. Dengan analisis tersebut juga dapat diketahui apakah pemenuhan ketenagaan ini sudah mempertimbangkan aspek efisiensi. Hasil penelitian ini dapat dimanfaatkan rumah sakit untuk mengelola sumber daya manusianya. Dengan menyeimbangkan tenaga kerja yang ada dengan beban kerja yang dihadapi akan dihasilkan suatu kepuasan kerja bagi karyawan, pelayanan kesehatan yang aman dan memuaskan bagi pasien dan efisiensi biaya SDM bagi rumah sakit.

\section{METODE}

Penelitian ini adalah penelitian deskriptif untuk menggambarkan kondisi ketenagaan riil RS HVA Toeloengredjo serta melihat perbedaan dengan kebutuhan ketenagaan berdasarkan hasil penghitungan WISN. Kondisi riil ketenagaan didapat dari sumber data di bagian Sub-divisi SDM Rumah Sakit HVA Toeloengredjo. Unit analisis penelitian ini meliputi unit pelayanan rawat jalan, rawat inap dan penunjang. Divisi Pemasaran dan Pengembangan Bisnis tidak dihitung karena dalam divisi tersebut ada bagian-bagian yang masih belum diisi ketenagaannya dan pemenuhan kebutuhan tenaganya menurut struktur organisasi yang ada. Divisi Administrasi, Keuangan dan SDM pemenuhan kebutuhan tenaga menurut struktur yang ada, dengan satu jabatan masih diisi satu orang tenaga. Selain itu beberapa formasi pekerjaan dipenuhi ketenagaannya dengan sistem outsourcing.

Data kegiatan rumah sakit diambil dari laporan kegiatan rumah sakit yang dilaporkan tiap bulan oleh rekam medis pada tahun 2012. Beban kerja standar dihitung melalui survei dimasing-masing sub-divisi dan dilakukan curah pendapat untuk mengidentifikasi jenis-jenis pekerjaan. Untuk kegiatan profesi dokter umum tidak dihitung karena selain kegiatan pelayanan medis juga melakukan kegiatan lain seperti: penyuluhan, siaran, rekonsiliasi dengan asuransi, dan kegiatan managed care.

Instrumen yang digunakan untuk menghitung kebutuhan 
tenaga sesuai beban kerja digunakan metode WISN (Workload Indicators of Staffing Need). Instrumen WISN sudah digunakan WHO sebagai dasar pemenuhan ketenagaan di sarana kesehatan di berbagai negara dan sudah diakui keandalannya. Keunggulan WISN adalah karena kemudahan dan kesederhanaan metodenya dan bisa diterapkan untuk berbagai profesi tidak hanya profesi kesehatan $(6,7)$.

Untuk menghitung kebutuhan tenaga dengan WISN yang pertama dilakukan adalah menghitung waktu kerja tersedia (WKT). Waktu kerja tersedia dihitung dari jam kerja harian dikalikan dengan jumlah hari kerja yang dilakukan dalam satu tahun. Waktu kerja tersedia ini akan berbeda-beda sesuai aturan rumah sakit. Misalnya jam kerja di bagian dapur sehari 8 jam dan dibagian perawatan satu hari 7 jam, dan dikalikan jumlah hari kerja setahun setelah dikurangi hari libur nasional, cuti dan kemungkinan hari tidak masuk kerja karena berbagai sebab.

Beban kerja dihitung melalui survei yang dilakukan masing-masing unit pelayanan. Setiap sub-divisi dibentuk tim untuk melakukan identifkasi macam-macam pekerjaan yang dilakukan setiap hari dan kebutuhan waktu untuk melakukan pekerjaan tersebut. Ditentukan pekerjaan-pekerjaan utama, penunjang dan tambahan. Pekerjaan utama adalah pekerjaan yang hasilnya tercatat dalam pencatatan statistik rumah sakit seperti: memeriksa pasien, memasang infus, melakukan injeksi dan lain-lain. Pekerjaan penunjang adalah pekerjaan yang dilakukan setiap tenaga dibagian tersebut yang tidak dicatat dalam statistik rumah sakit, biasanya pekerjaan penunjang adalah pekerjaan administrasi, persiapan kerja dan rapat sub-divisi. Pekerjaan tambahan adalah pekerjaan yang dilakukan oleh orang-orang tertentu di bagian tersebut dan tidak tercatat di statistik rumah sakit $(6,7)$.

Standar kegiatan adalah waktu yang dibutuhkan oleh seorang pekerja yang terdidik dan terlatih dengan baik, terampil dan berdedikasi untuk melaksanakan suatu kegiatan sesuai standar profesional dalam keadaan setempat (7). Ada dua standar kegiatan yaitu standar pelayanan dan standar kelonggaran. Standar pelayanan adalah standar kegiatan dari kegiatan-kegiatan yang baginya tersedia catatan statistik tahunan. Hal ini diukur sebagai waktu rata-rata yang dibutuhkan seorang tenaga kesehatan untuk melaksanakan kegiatan tersebut. Standar-standar kelonggaran adalah standar-standar kegiatan untuk kegiatan-kegiatan dimana tidak dilakukan pencatatan statistik tahunan secara teratur. Standar kelonggaran ditulis sebagai persentase dari waktu kerja sesungguhnya (6).

Setelah diketahui beban kerja yang ada maka dihitung beban kerja standar. Beban kerja standar dapat didefinisikan sebagai banyaknya kerja (dalam satu kegiatan pelayanan utama) yang dapat dilakukan oleh seorang tenaga kesehatan dalam setahun. Beban kerja standar diperoleh dengan membagi WKT setahun dengan unit waktu untuk kegiatan tertentu (7). Selanjutnya dihitung faktor kelonggaran kategori (FKK) dari standar kelonggaran kategori (SKK) yang ada. Standar kelonggaran kategori diperoleh dengan membagi waktu yang dilakukan untuk tiap kegiatan penunjang selama satu tahun dibagi dengan WKT dan diperoleh persentase waktu dari SKK. Semua nilai SKK dijumlahkan dan dihitung faktor kelonggaran kategori dengan rumus: FKK=1 dibagi dengan [1 dikurangi (Total SKK yang dibagi 100)] (6).

Faktor kelonggaran individu (FKI) memperhitungkan waktu kerja yang digunakan beberapa tenaga kesehatan untuk kegiatan-kegiatan tambahan. Faktor kelonggaran individu diperoleh dengan menghitung waktu yang digunakan beberapa petugas tersebut untuk semua kegiatan tambahan dalam setahun dan dibagi dengan waktu kerja tersedia (6).

Langkah pertama menghitung kebutuhan tenaga berdasarkan WISN adalah membagi beban kerja setahun dengan beban kerja standar yang akan diperoleh kebutuhan tenaga untuk kegiatan tersebut. Jumlahkan semua kebutuhan untuk setiap kegiatan-kegiatan utama dan diperoleh total kebutuhan pekerja untuk semua kegiatan pelayanan utama. Hasil penjumlahan dikalikan dengan FKK dan diperoleh jumlah kebutuhan tenaga untuk kegiatan utama dan penunjang. Hasil perhitungan tersebut ditambah dengan FKI maka diperoleh kebutuhan total pekerja untuk bagian tersebut berdasarkan WISN.

Sub-divisi yang dihitung kebutuhan tenaga kerjanya adalah sub-divisi di tiga divisi yaitu Divisi Pelayanan Medis (5 subdivisi), Divisi Penunjang Medis (6 sub-divisi) dan Divisi Keperawatan (8 sub-divisi). Dua sub-divisi dihitung secara terpisah menjadi dua bagian yaitu Instalasi farmasi dengan gudang obat dan instalasi gizi dengan bagian distribusi gizi.Pada kedua bagian tersebut dilakukan penghitungankebutuhan tenagasecara terpisah dari subdivisinya karena jenis pekerjaanya berbeda dengan subdivisi induknya.

\section{HASIL}

Hasil penghitungan kebutuhan tenaga kerja dengan metoda WISN dari sub-divisi di RS HVA Toeloengredjo disajikan pada Tabel 1. Dalam Tabel 1 disebutkan kondisi riil tenaga yang ada di masing-masing unit pelayanan. Dllakukan juga penghitungan kelebihan atau kekurangan tenaga kerja dibanding dengan hasil penghitungan WISN.

Tabel 1. Hasil penghitungan kebutuhan tenaga dengan metoda WISN

\begin{tabular}{|c|c|c|c|c|}
\hline \multirow[b]{2}{*}{$\begin{array}{l}\text { Sub-divisi / unit } \\
\text { pelayanan }\end{array}$} & \multicolumn{2}{|c|}{ Kebutuhan tenaga } & \multirow[b]{2}{*}{$\begin{array}{l}\text { Kelebihan / } \\
\text { Kekurangan } \\
\text { (c) }\end{array}$} & \multirow[b]{2}{*}{$\begin{array}{l}\text { Rasio } \\
\text { WISN } \\
\text { (a/b) }\end{array}$} \\
\hline & $\begin{array}{l}\text { Kondisi } \\
\text { saat ini } \\
\text { (a) }\end{array}$ & $\begin{array}{c}\text { Hasil WISN } \\
\text { (pembulatan) } \\
\text { (b) }\end{array}$ & & \\
\hline
\end{tabular}

\begin{tabular}{lcccc}
\hline Poliklinik & 2 & 2 & 0 & 1,00 \\
IGD & 11 & 8 & +3 & 1,38 \\
Hemodialisa & 4 & 3 & +1 & 1,33 \\
Poli Gigi & 6 & 5 & +1 & 1,20 \\
Rekam medis & 13 & 8 & +5 & 1,63 \\
Kandungan dan & 9 & 6 & +3 & 1,50 \\
bersalin & & & & \\
Irna Vinolia (VIP) & 13 & 11 & +2 & 1,18 \\
Irna Anggrek (I) & 13 & 11 & +2 & 1,18 \\
Irna Sakura (II) & 15 & 15 & 0 & 1,00 \\
Irna Dahlia (III) & 13 & 16 & -3 & 0,81 \\
Irna Mawar & 14 & 5 & +9 & 2,80 \\
(bedah) & & & & \\
ICU & 13 & 12 & +1 & 1,08 \\
Kamar operasi & 11 & 8 & +3 & 1,38 \\
Radiologi & 4 & 4 & 0 & 1,00 \\
Laboratorium & 8 & 5 & +3 & 1,60 \\
Instalasi farmasi & 13 & 12 & +1 & 1,08 \\
$\quad$ Gudang obat & 3 & 2 & +1 & 1,50
\end{tabular}


Tabel 1. Hasil penghitungan kebutuhan tenaga dengan metoda WISN (Lanjutan)

\begin{tabular}{|c|c|c|c|c|}
\hline \multirow[b]{2}{*}{$\begin{array}{l}\text { Sub-divisi / unit } \\
\text { pelayanan }\end{array}$} & \multicolumn{2}{|c|}{ Kebutuhan tenaga } & \multirow{2}{*}{$\begin{array}{l}\text { Kelebihan / } \\
\text { Kekurangan } \\
\text { (c) }\end{array}$} & \multirow{2}{*}{$\begin{array}{l}\text { Rasio } \\
\text { WISN } \\
\text { (a/b) }\end{array}$} \\
\hline & $\begin{array}{l}\text { Kondisi } \\
\text { saat ini } \\
\text { (a) }\end{array}$ & $\begin{array}{l}\text { Hasil WISN } \\
\text { (pembulatan) } \\
\text { (b) }\end{array}$ & & \\
\hline Instalasi Gizi & 12 & 9 & +3 & 1,33 \\
\hline Distribusi Gizi & 8 & 6 & +2 & 1,33 \\
\hline RT dan Linen & 9 & 6 & +3 & 1,50 \\
\hline Fisioterapi & 5 & 4 & +1 & 1,25 \\
\hline Jumlah & 199 & 158 & 41 & 1,26 \\
\hline
\end{tabular}

Hasil menunjukkan bahwa sebagian besar sub-divisi (15 sub-divisi) mempunyai kelebihan tenaga apabila dihitung sesuai beban kerja. Hanya tiga sub-divisi yang mempunyai tenaga sesuai beban kerja yaitu poliklinik, Irna Sakura (II) dan radiologi. Satu sub-divisi mempunyai ketenagaan yang kurang (-3) yaitu Irna Dahlia (III). Kelebihan tenaga yang terjadi, mempunyai kisaran antara lebih 1 orang hingga 9 orang per sub-divisi. Kelebihan tenaga terbanyak terjadi di sub-divisi Irna Mawar (Bedah) sebanyak 9 orang.

Beberapa sub-divisi memberikan pelayanan dalam dua kurun waktu yaitu pagi dan sore, sebagian lagi memberikan pelayanan 24 jam sehari dan 7 hari perminggu. Sub-divisi poliklinik, poliklinik gigi, radiologi, fisioterapi, kamar operasi, rumah tangga dan linen, hemodialisa dan Instalasi gizi memberikan pelayanan dalam dua kurun waktu dalam satu hari. Sub-divisi laboratorium, Instalasi Gawat Darurat, Instalasi rawat inap, instalasi farmasi, kandungan dan bersalin, ICU dan rekam medis memberikan pelayanan selama 24 jam perhari.

Dari perhitungan WISN pada 19 sub-divisi pelayanan diperoleh hasil kebutuhan tenaga berdasarkan kegiatan kerja pada tahun 2012 sebesar 158 orang dan saat ini tenaga yang ada di 19 sub-divisi tersebut berjumlah 199 orang yang berarti terjadi kelebihan 41 tenaga kerja. Rasio WISN total dari 19 sub-divisi yang dihitung sebesar 1,26, berarti terjadi kelebihan tenaga kerja lebih dari $25 \%$ dari kebutuhan. Pada Tabel 1 terdapat enam sub-divisi yang mempunyai rasio WISN lebih atau sama dengan 1,5 yaitu sub-divisi rekam medis, kandungan dan bersalin, Irna Mawar (Bedah), laboratorium, gudang obat dan sub-divisi Rumah Tangga dan Linen.

\section{DISKUSI}

Workload Indicators of Staffing Need adalah suatu metoda atau alat manajemen sumber daya manusia untuk menentukan kebutuhan tenaga kerja guna mengatasi beban kerja di suatu fasilitas kerja. Keunggulan WISN ini adalah: sederhana dan mudah digunakan, bisa digunakan untuk berbagai profesi, menyeluruh dan reliable, bisa digunakan untuk perencanaan dan evaluasi ketenagaan (7). Perhitungan WISN membutuhkan data-data kegiatan rumah sakit. Data ini digunakan untuk menghitung beban kerja pada kegiatan utama dan perlu diketahui alokasi waktu untuk melaksanakan jenis kegiatan utama tersebut untuk menentukan beban kerja standar.

Hasil penghitungan pada 19 sub-divisi dengan metoda WISN didapatkan hasil sebesar 158 orang yang berarti terdapat selisih sebesar 41 orang dari ketenagaan yang ada saat ini sebesar 199 orang. Rasio WISN yang dihasilkan sebesar 1,26 yang menunjukkan terdapat kelebihan hingga lebih dari $25 \%$ tenaga kerja. Ini tentu membawa implikasi biaya SDM yang besar karena setiap tenaga kerja membawa konsekuensi biaya yang harus dikeluarkan berupa gaji, lembur, bonus, biaya pelatihan, dan biaya perawatan kesehatan.

Penyediaan tenaga perawat yang cukup memang akan memberikan peningkatan kualitas pelayanan kesehatan dan bisa mengurangi burnout dan ketidakpuasan perawat. Aiken, meneliti hubungan antara jumlah perawat dengan kematian pasien, burnout dan ketidakpuasan kerja didapat bahwa kematian pasien meningkat bila rasio antara pasien-perawat juga meningkat. Semakin dinaikkan rasio pasien-perawat semakin meningkat pula kejadian burnout dan ketidak puasan kerja yang pada akhirnya meningkatkan keinginan untuk pindah kerja $(1,2,8)$. Penelitian lain ada yang berpendapat sebaliknya. Pada pelayanan kesehatan menggunakan sistem managed care, dimana rumah sakit dibayar dengan cara paket seperti DRG atau INA CBGs. Rumah sakit dengan persaingan yang ketat akan menyeimbangkan biaya akibat kelebihan tenaga. Rumah sakit akan mengurangi biaya pada beberapa pos biaya seperti biaya pelatihan, biaya pengembangan teknologi atau tes-tes tambahan bagi pasien yang berakibat menurunkan kualitas pelayanan rumah sakit (3).

Kelebihan tenaga pada tingkat sub-divisi bervariasi dari kelebihan 1 orang hingga 9 orang. Pada sub-divisi Irna Mawar terjadi kelebihan tenaga paling besar (+9) dengan WISN rasio 2,80. Hal ini terjadi karena kegiatan di sub-divisi Irna Mawar yang rendah. Kegiatan yang rendah terutama pada pasien captive pabrik gula. Penyebab lain adalah tidak ada pencatatan kegiatan di luar daftar tarif seperti kegiatan mengantar pasien ke unit penunjang. Kelebihan terbanyak kedua terjadi pada sub-divisi rekam medis (+5) dengan WISN rasio 1,63 . Sub-divisi rekam medis yang terdiri dari pelayanan pendaftaran dan rekam medis sendiri. Terjadinya kelebihan ini mungkin berhubungan dengan pelayanan rekam medis yang buka 24 jam dimana kegiatan di malam hari yang sedikit tetapi rekam medis harus tetap menyediakan tenaga untuk jaga pada shift malam. Penghitungan beban kerja petugas pendaftaran yang kurang lengkap mengakibatkan terjadi kelebihan tenaga yang besar. Petugas pendaftaran selain mendaftar pasien yang kegiatannya tercatat dilaporan rekam medis sebagai kunjungan pasien, juga bertugas memberikan informasi dan memberikan penjelasan kepada orangorang yang bertanya tentang pelayanan rumah sakit dan tempat pasien dirawat inap. Kegiatan memberikan informasi ini tidak tercatat di laporan sehingga petugas pendaftaran terlihat mempunyai beban kerja yang kecil.

Kelebihan terbesar selanjutnya adalah sub-divisi laboratorium $(+3)$ dengan rasio WISN 1,60. Kelebihan ini bisa terjadi karena beban kerja yang tinggi pada kegiatan sampling, input data dan administrasi serta adanya kewajiban mengantarkan hasil laboratorium ke ruangan. Laboratorium yang buka 24 jam juga memberikan kontribusi kelebihan tenaga karena kegiatan di malam hari tidak banyak. Laboratorium harus berkoordinasi dengan instalasi rawat inap untuk penjadwalan sampling sebaiknya dalam satu hari tidak lebih empat kali melakukan sampling karena kegiatan ini sangat menyita waktu. Hal itu disebabkan kondisi Rumah Sakit HVA 
Toeloengredjo yang luas dan gedung-gedung yang terpisah oleh taman menyebabkan jarak yang ditempuh petugas menjadi jauh bila harus berpindah antar ruangan. Jadwal kunjungan dokter spesialis ke pasien rawat inap yang tidak tentu menjadi salah satu faktor yang menyebabkan kegiatan sampling tidak dapat diprediksi.

Kekurangan tenaga terjadi di sub-divisi Irna Dahlia (-3) yang merupakan ruangan kelas III dan isolasi. Di sini kekurangannya cukup besar hingga kurang tiga orang dengan rasio WISN 0,81. Kekurangan tenaga ini berhubungan dengan hari perawatan di Irna Dahlia yang tinggi, dan itu menunjukkan beban kerja yang besar. Pada kondisi kekurangan tenaga seperti ini kemungkinan akan mempengaruhi kualitas pelayanan kepada pasien. Perawat mendapat beban kerja yang berat dan akhirnya perawat akan mengurangi waktu beberapa jenis pekerjaan seperti edukasi ke pasien, pekerjaan administrasi dan pekerjaan lain yang bisa mempengaruhi keselamatan pasien. Suatu penelitian di ruang NICU menunjukkan bahwa peningkatan kematian dan kejadian infeksi nosokomial sebanding dengan kenaikan beban kerja $(9,10)$. Penelitian lain juga menunjukkan bahwa kekurangan tenaga kerja menyebabkan performa dan hasil yang buruk di pelayanan perinatal (11). Kekurangan perawat juga berakibat kepada kejadian burnout dan ketidakpuasan perawat yang akhirnya berakibat kenaikan keinginan untuk pindah kerja $(1,2,8,12)$. Kepuasan pasien terhadap pelayanan rumah sakit juga menurun ketika terjadi kenaikan burnout dan ketidakpuasan perawat (12). Pemenuhan kebutuhan perawat dan lingkungan kerja yang baik, seperti adanya dukungan manajemen, hubungan dokter-perawat yang baik dan pelibatan perawat dalam pengambilan keputusan, berhubungan dengan kepuasan pasien, kualitas dan keselamatan pelayanan dan produktifitas perawat. Oleh karena itu dengan memperbaiki lingkungan kerja dan pemenuhan kebutuhan perawat akan menghasilkan outcome pasien yang lebih baik (12).

Kelebihan tenaga di rumah sakit bisa diakibatkan oleh berapa hal. Rumah sakit berusaha memberikan keunggulan atas rumah sakit yang lain dengan cara menyediakan pelayanan yang cepat, pelayanan yang buka 24 jam setiap hari, membuat pelayanan unggulan walaupun utilitasnya mungkin rendah (3). Pelayanan 24 jam perhari dan 7 hari perminggu seperti IGD akan mendorong unit penunjang ikut memberikan pelayanan seperti IGD, karena unit-unit itu harus mengikuti jam pelayanan IGD, contohnya bagian pendaftaran, instalasi farmasi dan laboratorium (14). Ketika kegiatan di unit tersebut fluktuatif akan membuat beban kerja lebih rendah dari kapasitas kerja yang tersedia pada waktu tertentu dan mempunyai beban kerja yang tinggi di waktu lain (14). Pihak manajemen tentu tidak akan menyediakan tenaga seminimal mungkin, karena ketika ada kenaikan aktivitas, tenaga di unit tersebut akan kewalahan memberikan pelayanan, yang akan berakibat kepada outcome pasien. Manajemen juga harus menyediakan tenaga jaga di unit yang buka 24 jam walaupun kegiatannya sedikit. Rumah Sakit HVA Toeloengredjo mempunyai area yang luas dan jarak antar ruang pelayanan cukup jauh. Petugas harus berpindah dari satu

\section{DAFTAR PUSTAKA}

1. Beswick S, Hill PD, and Anderson MA. Comparison of Nurse Workload Approaches. Journal of Nursing Management. 2010; 18(5): 592-598. ruangan ke ruangan lain yang membutuhkan waktu yang cukup banyak. Akibat dari jarak tersebut kegiatan menjadi lebih lama dari seharusnya dan ini akan menimbulkan kebutuhan tenaga lebih besar dari semestinya.

Hasil penghitungan kebutuhan tenaga dengan WISN sangat tergantung kepada ketepatan data kegiatan rumah sakit. Pada penelitian ini kegiatan-kegiatan yang angkanya kecil sebagian tidak dimasukkan dalam penghitungan karena dampaknya sangat kecil pada beban kerja utama. Ada beberapa kegiatan di rawat inap yang tidak sama antar ruangan dikarenakan perbedaan item laporan. Penghitungan beban kerja standar sangat tergantung kepada kejujuran petugas untuk mengukur lama pelaksanaan pekerjaannya. Kadang kala petugas berusaha memperpanjang waktu pelaksanaan pekerjaannya agar mendapat penghitungan kebutuhan tenaga yang besar supaya tenaga di unitnya tidak dikurangi. Kegiatan yang dicatat, untuk saat ini masih didasarkan pada kegiatan yang tercatat pada daftar tarif rumah sakit. Untuk penelitian WISN yang akan datang, penulis sarankan untuk lebih detail dalam mengukur beban kerja standar dan mempertimbangkan untuk mencatat kegiatan-kegiatan yang tidak ada di daftar tarif rumah sakit seperti pemberian informasi, edukasi dan mengantar pasien karena kegiatan tersebut menyita waktu petugas (15). Apabila pekerjaan tersebut tidak dihitung akan memberikan hasil kebutuhan tenaga yang lebih sedikit dari seharusnya. Rumah sakit perlu mencatat kegiatan pendidikan dan pelatihan supaya bisa dimasukkan ke dalam beban kerja, karena dalam penelitian ini tidak ada sub-divisi yang mencantumkan kegiatan pendidikan dan pelatihan dalam beban kerjanya. Selain itu, petugas perlu membudayakan pendokumentasian setiap kegiatan untuk tertib administrasi.

Kelebihan tenaga kerja di RS HVA Toeloengredjo memberikan pengaruh kepada biaya SDM yang tinggi, dan tampak pada rasio antara biaya SDM terhadap pengeluaran. Kelebihan tenaga kerja tersebut dikarenakan pelayanan yang buka 24 jam dan 7 hari seminggu dan mendukung kegiatan yang diunggulkan oleh rumah sakit. Hal tersebut menjadi salah satu alasan bagi rumah sakit untuk memenuhi kebutuhan tenaga kerja, meskipun kegiatan di beberapa unit mungkin rendah atau kegiatan yang terjadi tidak sebanyak kapasitas yang bisa dicapai. Sebelum hasil ini diterapka SDM perlu mengkaji hasil penghitungan WISN dengan kebutuhan minimal tenaga yang ada. Kadang kala ada suatu unit pelayanan yang harus buka melayani masyarakat sebagai pemenuhan peraturan pemerintah walaupun utilitasnya kecil. Pengelola SDM tidak harus memindah petugas dari tempat yang lebih ke yang kurang, tetapi akan lebih baik apabila menggeser beban kerja dari yang lebih ke yang kurang dan mengkaji jenis-jenis pekerjaan yang ada. Pelayanan yang cepat, tepat waktu dan jam pelayanan yang fleksibel atau 24 jam menjadi strategi manajemen untuk memenangkan pasar. Kelebihan tenaga juga akibat karena tidak ada pencatatan kegiatan diluar daftar tarif pelayanan rumah sakit. Kondisi rumah sakit yang luas juga berperan menyebabkan kebutuhan tenaga meningkat. Konsekuensi dari kelebihan tenaga adalah biaya sumber daya manusia yang besar.

2. MacPhee M, Ellis J, and Sanchez MA. Nurse Staffing and Patient Safety. Canadian Nurses Association. 2006; 102(8): 18-23.

3. Mobley LR and Magnussen J. The Impact of Managed 
Care Penetration and Hospital Quality on Efficiency in Hospital Staffing. Journal of Health Care Finance. 2002; 28(4): 24-42.

4. Mulyadi. Akuntansi Biaya. Edisi 5. Yogyakarta: UPPSTIM YKPN; 2010.

5. Machfoedz M. Akuntansi Manajemen. Edisi 5. Yogyakarta: STIE-Widya Wiwaha; 1996.

6. Departemen Kesehatan Republik Indonesia. Buku Pedoman Pengembangan Indikator Beban Kerja Petugas \{Workload Indicators of Staffing Need (WISN)\} Untuk meningkatkan Perencanaan dan Pengelolaan Tenaga Kerja. Jakarta: Depkes Rl; 2009.

7. World Health Organization. Workload Indicators of Staffing Need User's Manual (WISN). Geneva: WHO Press; 2010.

8. Aiken LH, Clarke SP, Sloane DM, Sochalski J, and Silber $\mathrm{JH}$. Hospital Nurse Staffing And Patient Mortality, Nurse Burnout, and Job Dissatisfaction. The Journal of The American Medical Association. 2002; 288(16): 1987-1993.

9. Tucker J. Patient Volume, Staffing, and Workload in Relation to Risk-Adjusted Outcomes in a Random Stratified Sample of UK Neonatal Intensive Care Units: A Prospective Evaluation. The Lancet. 2002; 359(9301): 99-107.
10. Pearson A, Pallas LO, Thomson D, et al. Systematic Review of Evidence on the Impact of Nursing Workload and Staffing on Establishing Healthy Work Environments. International Journal of EvidenceBased Healthcare. 2006; 4(4):337-384.

11. Nyamtema AS, Urassa DP, Massawe $S$, Massawe A, Lindmark G, and Van Roosmalen J. Staffing Needs for Quality Perinatal Care in Tanzania. African Journal of Reproductive Health. 2008; 12(3): 113-124.

12. Aiken LH, Sermeus W, Heede KVd, et al. Patient Safety, Satisfaction, and Quality of Hospital Care: Cross Sectional Surveys of Nurses and Patients in 12 Countries in Europe and The United States. British Medical Journal. 2012; 344: e1717.

13. Shirley J and Wing S. Workload, Organisation, and Cost of Haematology Laboratory Out of Hours Services. Journal of Clinical Pathology. 2001; 54(8): 647-649.

14. Debergh DP, Myny D, Van Herzeele I, Van Maele G, Miranda DR, and Colardyn F. Measuring the Nursing Workload Per Shift in the ICU. Intensive Care Medicine. 2012; 38(9): 1438-1444.

15. Ernawati NLAK, Nursalam, and Djuari L. Kebutuhan Riil Tenaga Perawat dengan Metode Workload Indikator Staff Need (WISN). Jurnal Ners. 2011; 6(1): 86-93. 